April 2011

\title{
Mass Atrocity Response Operations: Doctrine in Search of Strategy
}

Alan J. Kuperman

Follow this and additional works at: https://digitalcommons.usf.edu/gsp

\section{Recommended Citation}

Kuperman, Alan J. (2011) "Mass Atrocity Response Operations: Doctrine in Search of Strategy," Genocide Studies and Prevention: An International Journal: Vol. 6: Iss. 1: Article 8.

Available at: https://digitalcommons.usf.edu/gsp/vol6/iss1/8

This Articles is brought to you for free and open access by the Open Access Journals at Digital Commons @ University of South Florida. It has been accepted for inclusion in Genocide Studies and Prevention: An International Journal by an authorized editor of Digital Commons @ University of South Florida. For more information, please contact digitalcommons@usf.edu. 


\title{
Mass Atrocity Response Operations: Doctrine in Search of Strategy
}

\author{
Alan J. Kuperman \\ Associate Professor, LBJ School of Public Affairs, \\ University of Texas at Austin
}

Most literature produced in the past two decades on the prospects of intervention to prevent genocide can be summed up by a cliché: "Where there's a will, there's a way." ${ }^{1}$ In that context, a vital if imperfect corrective is provided by MARO: Mass Atrocity Response Operations; A Military Planning Handbook (henceforth, MARO), produced jointly by Harvard University and the US Army. Contrary to the naïve optimism of many past analyses, this report starts with the fact that, without feasible options, effective humanitarian military intervention is unlikely, if not impossible.

As MARO makes clear from the outset, "the failure to act in the face of mass killings of civilians is not simply a function of political will or legal authority; the failure also reflects a lack of thinking about how military forces might respond."2 Accordingly, the report details precisely how such forces could intervene, in hopes that they will be better prepared and more likely to act in future crises. The report's guiding ethos could thus be summed up by reversing the cliché: "Where there's a way, there's a will."

By focusing on practical matters, rather than wishful thinking, MARO is a vast improvement over the 2008 report of the Genocide Prevention Task Force, chaired by Madeleine Albright and William Cohen, Preventing Genocide: A Blueprint for U.S. Policymakers. ${ }^{3}$ Unlike that previous report, MARO lays out an impressive spectrum of realistic military options, ranging from deterrent threats to full-blown military occupation, which could prevent or mitigate genocide $(20 ; 65-87)$. The new report also includes the dry doctrinal language that would be necessary for a huge bureaucracy like the US military to implement such a policy.

$M A R O$ builds upon three important lessons from the past (17-18). First, intervention creates a strategic interaction between at least three players-the two (or more) parties involved in the conflict plus the interveners-so its precise consequences are unpredictable (25-26). Second, intervention is almost never neutral. Even if interveners provide aid impartially—that is, to all sides based exclusively on need-they inevitably will alter the balance of power in a conflict. ${ }^{4}$ Third, widespread killing and expulsion can be, and often are, perpetrated remarkably quickly, so if intervention builds only gradually-as the domestic politics of the intervening states typically necessitate-it will likely fail to prevent such atrocities (29). ${ }^{5}$

The report then addresses stubborn military realities (18). For example, in airborne interventions especially, there is an unavoidable trade-off between the speed of deployment and the weight of armor and equipment used to protect intervening forces. In other words, it takes longer to deploy well-protected forces. Yet, quicker interventions can save more lives. As a result, there is also a painful trade-off between how many potential victims will be protected and how many interveners

Alan J. Kuperman, "Mass Atrocity Response Operations: Doctrine in Search of Strategy," Genocide Studies and Prevention 6, 1 (April 2011): 59-65. (C) 2011 Genocide Studies and Prevention. doi:10.3138/gsp.6.1.59 
will be killed or wounded in the process. Hypothetically, a lighter intervening forcethat is, one without armored vehicles, helicopters, and artillery-might deploy three times as fast and save 10,000 more lives, but at the cost of 50 more intervener casualties. Would such a trade-off be worthwhile? Who should decide? MARO does not answer such questions or even explore them in detail, but deserves credit for acknowledging them rather than pretending, as have many previous analyses, that all such challenges can be overcome by political will.

$M A R O$ also astutely recommends advance planning for specific military interventions. Very few countries actually are at risk of genocidal violence, and experts are generally able to identify them. ${ }^{6}$ If military planning teams were provided several months to research past patterns of violence and current political trends in these states, they would be able to pinpoint the most likely perpetrators and targets of atrocities, the locations and means of entry for interveners, the potential staging bases in neighboring states, and the best strategies to stanch violence. Such advance planning would make intervention much faster and more effective when and if deployment orders ever came, potentially saving tens or even hundreds of thousands more lives in a case such as the 1994 Rwandan Genocide.

Full-blown intervention is not the only type that can prevent atrocities, as the report accurately observes, because smaller-scale deterrent operations also can decisively affect outcomes (65-69). An excellent example, not cited in $M A R O$, took place in Liberia in 2003. The mere deployment of US Marines off the coastaccompanied by military over-flights, deft diplomacy, a regional peacekeeping contingent, and a small evacuation force-successfully persuaded President Charles Taylor to leave office, thereby ending a savage civil war and alleviating a humanitarian emergency for tens of thousands of displaced civilians. ${ }^{7}$

Despite these many attributes, $M A R O$ is marred by two shortcomings. First, it focuses mainly on military operations to the relative neglect of political strategies and consequences. Second, it often relies on a simplistic, idealized conflict scenario, giving rise to intervention proposals that could backfire in more realistic and complex settings. Although $M A R O$ refers in passing to "second-order" $(40 ; 52 ; 68)$ and "third-order" (27; 40) effects of military intervention, ${ }^{8}$ it largely ignores the implications of such "system effects," which, as Robert Jervis has noted, can radically alter policy prescriptions. ${ }^{9}$ The report explicitly avoids complex policy questions about intervention, stating that "The MARO Project itself is concerned with answering the 'how,' not the 'whether'" (13). Unfortunately, since military intervention can unintentionally increase the likelihood of atrocities, the "how" of intervention is inextricably linked to debates about "whether" such action is advisable.

\section{Strategy versus Operations}

The Prussian military officer Carl von Clausewitz famously noted that war is "a continuation of political intercourse carried on with other means." 10 While this dictum is well known, its policy implications are less widely understood. Clausewitz was criticizing the tendency_-still prevalent today_of war planning to focus more on military operations than on the achievement of underlying political objectives. Essentially, he warned against winning the battle while losing the war. Or, as he summed it up, military "means can never be considered in isolation from their purpose." 11

Modern scholars and practitioners of military arts have institutionalized this lesson via an analytical prism comprising three levels of analysis that represent progressively wider scope: tactics, operations, and strategy. Tactics refer to the ways 
in which force is utilized locally to achieve small-scale military objectives. Operations refer to the ways in which tactics are utilized on a wider scale to achieve broader military objectives. Strategy refers to the ways in which military operations are utilized to achieve political objectives.

$M A R O$, as its title indicates, focuses on military operations. This is necessary, but not sufficient. Since the advent of widespread humanitarian military intervention in the 1990s, such operations have frequently backfired strategically, by increasing civilian suffering, contrary to their political objective. From a Clausewitzian perspective, interveners often win the battle but lose the war. For example, in 1999, NATO bombing accomplished its military objective by compelling the retreat of Yugoslav forces from Kosovo. But it failed strategically by unintentionally amplifying the killing and expulsion of ethnic Albanian civilians-five-fold, at minimum-and then enabling the revenge killing and expulsion of ethnic Serb civilians. ${ }^{12}$ This outcome was precisely opposite to NATO's stated humanitarian objective of protecting civilians.

The only way to avert such perverse outcomes is to design military operations with an eye to strategy based on realistic scenarios that draw upon accurate descriptions of past interventions. Unfortunately, here too $M A R O$ sometimes falls short.

\section{White and Black Hats}

The greatest flaw of MARO is that it assumes that most atrocities are committed in the context of one-way violence by a state against its civilians. The report thus views intervention as having the straightforward effect of stopping the bad guys and protecting the good guys, with assistance from non-governmental and multilateral organizations. ${ }^{13}$ As it summarizes, "The four categories [of actors] include: perpetrators, victims, interveners, and a more nebulous group of 'others'" (44).

In reality, as scholars have long documented but only recently emphasized, most atrocities by states are committed in response to rebel challenges, including armed secession. States typically target civilians who are suspected of supporting, harboring, or secretly being rebels. From 1943 to 1987, Harff and Gurr identified 44 episodes of "genocide and politicide," state-sponsored campaigns lasting at least six months that deliberately killed thousands of noncombatants. ${ }^{14}$ In 30 of those 44 cases $(68 \%)$, as I observed in a 2005 analysis, rebels provoked the state's retaliation against civilians. ${ }^{15}$ In a separate study, Helen Fein identified 19 cases of genocide from 1945 to 1988. She similarly concluded that "one could classify at least 11 cases [58\%] as retributive genocide in which the perpetrators retaliated to a real or perceived threat by the victim to the structure of domination." 16 In a more recent quantitative analysis, Benjamin Valentino, Paul Huth, and Dylan Balch-Lindsay likewise find that atrocities are best explained as a state strategy to "drain the sea" of rebels. ${ }^{17}$

Because of these complex dynamics, international efforts to protect at-risk civilians, as called for by the emerging norm of the Responsibility to Protect, can perversely backfire by exacerbating violence. This is so because intervention to defend targeted civilians, whether through military or diplomatic action, often has the effect of also protecting and assisting rebels. This emboldens the rebels to escalate their attacks against the state, provoking still greater atrocities. In some cases, rebels even deliberately provoke state retaliation against civilians to attract international intervention. Over the last two decades, this moral-hazard dynamic has exacerbated atrocities in three of the worst cases: Bosnia, Kosovo, and Darfur. ${ }^{18}$ 
A pre-publication draft of $M A R O$ failed almost entirely to contemplate this dynamic. Only one sentence in an appendix noted that international deterrent operations "may inspire opposition groups to increase any activities that may have been contributing to the situation and prompt a harsh governmental response." Following comments from me (and perhaps others), MARO moved that sentence into the main text and added that opposition groups may try to "manipulate an intervention by external parties" (68). The final report also warns that "rebel groups may conduct mass atrocities to intimidate populations, undermine the government's legitimacy, or provoke the government into a disproportionate response" (45). These are important correctives. But $M A R O$ still fails to address the implications for strategy, because it focuses nearly exclusively on military operations. ${ }^{19}$ As a result, the report prescribes military action that could mitigate some atrocities but might exacerbate others, thereby potentially increasing the total violence against civilians, constituting strategic failure.

The report's simple scenario of good versus bad guys also distorts lessons from the past. In Rwanda, for example, $M A R O$ explains the victimization of both of the country's main ethnic groups as follows: "Rwandan [Hutu] genocidaires killed moderate Hutu in addition to Tutsi" (39). This ignores long-standing evidence that the invading Tutsi rebels, known as the Rwandan Patriotic Front, themselves killed tens of thousands of Rwandan Hutu civilians before, during, and after the genocide, thereby helping provoke and fuel the massacres by Hutu extremists. ${ }^{20}$ Ironically, the report cites only the Hutu for using media "to attempt to control, or decisively shape, the information environment" (55). In actuality, worldwide media reported Hutu crimes within weeks but failed to report Tutsi crimes for nearly 15 years because the propaganda of the rebels successfully blamed the Hutu for all atrocities and impeded UN investigations. $M A R O$, in this instance, falls victim to precisely the kind of information operations that it warns against.

The history of rebel provocation also calls into question the report's policy prescriptions. For example, MARO insists repeatedly that increased international "witness" and "transparency" of atrocities, through better surveillance and reporting, would deter perpetrators (35-36). That is possible. But the literature on moral hazard reveals that sub-state actors sometimes rebel precisely because they expect media reports of the state's retaliation to compel intervention on their behalf. If so, greater reporting of state atrocities would actually increase the incentive for rebel provocations. It remains unclear, therefore, whether heightened "witness" of atrocities would increase or decrease such violence.

Finally, MARO's prescriptions ignore a broad body of literature illustrating how even purely humanitarian aid, such as food, water, sanitation, shelter, and medical care, may exacerbate conflict. ${ }^{21}$ For example, militants often intermingle with civilians in refugee camps, so the aid may sustain the rebels and inhibit their reintegration into society, thereby prolonging fighting. Combatants sometimes intercept aid and resell it or charge a tax for its safe delivery, helping to fund war. In some cases, factions even fight each other to control delivery of aid, creating an extra incentive for violence. Humanitarian aid also may damage the local economy by under-pricing nearby merchants and producers, and it can delegitimate local political authorities by providing better services than the government. In addition, aid organizations often hire away the best-skilled local residents to serve as translators, drivers, or office staff, draining the human capital necessary for entrepreneurship and good governance. Unless such historical lessons are incorporated into military doctrine, future interventions are likely to repeat the mistakes of the past. 


\section{Military Doctrine Is Not Enough}

The noble objective of reducing mass atrocities requires a multi-pronged strategy. First, the international community should pursue preventive rather than pyromaniac diplomacy. As noted above, states are most likely to perpetrate atrocities when confronted with violent domestic threats to their rule. Thus, diplomacy should emphasize consensual mediation, and carrots rather than sticks, to facilitate negotiated outcomes. By contrast, coercing a state to hand over power or territory to a domestic challenger is extremely dangerous because it heightens the risk that the state will resort to atrocities to retain control. ${ }^{22}$ Diplomats should avoid such muscular mediation unless they also take steps to avert the likely backlash-for example, by providing soft landings for senior officials of the departing regime, or by pre-deploying a robust peacekeeping force. ${ }^{23}$

Second, the United States and its allies should adopt criteria for intervention that minimize moral hazard. ${ }^{24}$ Most importantly, they should refrain from helping rebels on humanitarian grounds unless state retaliation is grossly disproportionate, in order to provide both sides with an incentive to reduce violence. Interveners should also deliver humanitarian aid in ways that minimize its benefit to rebels, by guarding the supply routes and camps where assistance is provided to threatened populations.

Third, the United States should structure and base its military forces in ways that facilitate rapid reaction, because speed saves lives. Several "ultra-light" brigades should be designed and equipped so that they can deploy and operate without significant armor or heavy weapons in relatively permissive threat environments. To further reduce deployment time, some units or at least their equipment should be pre-positioned at bases in Africa, where mass atrocities are most likely to occur.

Finally, as MARO proposes, the United States and other like-minded states should adopt military doctrine to stop atrocities. Yet, even here, caution is required. Such routinization of intervention by itself could do more harm than good by further emboldening rebels to provoke state retaliation in expectation of the benefits from the humanitarian response. Only if properly embedded in a comprehensive strategyincluding enlightened diplomacy, strict intervention criteria, and well-designed forces-would MARO's proposed doctrine contribute unambiguously to the protection of at-risk civilians and thereby help implement the emerging norm of the Responsibility to Protect.

\section{Notes}

1. This simplistic approach is epitomized in Samantha Power, "A Problem from Hell:" America and the Age of Genocide (New York: Basic Books, 2002). By way of contrast, a few previous works have focused on the practical challenges of humanitarian military intervention. See, for example, Alan J. Kuperman, The Limits of Humanitarian Intervention: Genocide in Rwanda (Washington, DC: Brookings Institution, 2001); Clifford H. Bernath and David C. Gompert, "The Power to Protect: Using New Military Capabilities to Stop Mass Killings," Refugees International, July 2003, http://www.reliefweb.int/ library/documents/2003/ri-gen-31jul.pdf; Taylor B. Seybolt, Humanitarian Military Intervention: The Conditions for Success and Failure (Oxford: Oxford University Press, 2007); Douglas C. Peifer, Stopping Mass Killings in Africa: Genocide, Airpower, and Intervention (Montgomery, AL: Air University Press, 2008). In addition, several graduate student papers from my courses on humanitarian intervention have been published, including, Benedikt F. Franke, "The Use of Sustained Coercive Air Power in Humanitarian Interventions," Journal of Humanitarian Assistance (Summer 2004), http://www.jha.ac/ articles/a170.pdf; Leslie Hough, "A Study of Peacekeeping, Peace Enforcement and 
Private Military Companies in Sierra Leone," African Security Review 16, no. 4 (2007): 821; Costantino Pischedda, "A Plan for Military Intervention in Darfur," African Security Review 16, no. 4 (2007): 80-96.

2. Sarah Sewall, Dwight Raymond, and Sally Chin, MARO: Mass Atrocity Response Operations; A Military Planning Handbook (Cambridge, MA: Harvard Kennedy School / Carr Centre for Human Rights Policy, 2010), 5. Subsequent references appear parenthetically in the text.

3. For a critique of that initiative, see Alan J. Kuperman, "Wishful Thinking Will Not Stop Genocide: Suggestions for a More Realistic Strategy," Genocide Studies and Prevention 4, no. 2 (2009): 191-99.

4. This point was originally highlighted in Richard K. Betts, "The Delusion of Impartial Intervention," Foreign Affairs, 73, no. 6 (1994): 20-33. For further discussion, see Alan J. Kuperman, "Humanitarian Intervention," in Human Rights: Politics and Practice, ed. Michael Goodhart (Oxford: Oxford University Press, 2009), 336-37.

5. For examples of such rapid violence, see Alan J. Kuperman, "Rethinking the Responsibility to Protect," Whitehead Journal of Diplomacy and International Relations 10, no. 1 (2009): 35 .

6. Several such watch-lists are accessible from the Genocide Prevention Advisory Network, http://www.gpanet.org/content/global-risks.

7. Alan J. Kuperman, "A Small Intervention: Lessons from Liberia 2003," in Naval Peacekeeping and Humanitarian Operations: Stability from the Sea, ed. Jim Wirtz and Jeff Larsen (Abingdon: Routledge, 2009), 153-169.

8. MARO states, "Choosing from among competing courses of action should also be informed by analysis of the likely effect of intervention upon the calculations and actors of other parties, and the third-order effects of their adjustments upon each other" (27). Unfortunately, the report does not heed that advice.

9. Robert Jervis, System Effects: Complexity in Political and Social Life (Princeton, NJ: Princeton University Press, 1998).

10. Carl von Clausewitz, On War, trans. Michael Howard and Peter Paret (Princeton, NJ: Princeton University Press, 1984), 87.

11. Ibid.

12. Alan J. Kuperman, "Averting the Third Kosovo War," The American Interest, 3, no. 3 (2008): 52-58.

13. MARO briefly mentions the possibility that sub-state groups may be armed and involved in "mutual violence" (23;44;46), but fails to explore the implications.

14. Barbara Harff and Ted Robert Gurr, "Toward an Empirical Theory of Genocides and Politicides," International Studies Quarterly 32 (1988): 359-71.

15. Alan J. Kuperman, "Suicidal Rebellions and the Moral Hazard of Humanitarian Intervention," Ethnopolitics, 4, no. 2 (2005): 150-51.

16. Helen Fein, "Genocide: A Sociological Perspective," Current Sociology 38, no. 1 (1990): 1126.

17. Benjamin Valentino, Paul Huth, and Dylan Balch-Lindsay, “'Draining the Sea:' Mass Killing and Guerrilla Warfare," International Organization 58, no. 2 (2004): 375-407.

18. Alan J. Kuperman, "The Moral Hazard of Humanitarian Intervention: Lessons from the Balkans," International Studies Quarterly 52, no. 1 (2008): 49-80. Alan J. Kuperman, "Darfur: Strategic Victimhood Strikes Again?" Genocide Studies and Prevention 4, no. 3 (2009): 281-303.

19. MARO's sole mention of strategy is in the book's first sentence (5).

20. See, for example, Raymond Bonner, "U.N. Stops Returning Rwandan Refugees," New York Times, 28 September 1994; Andre Picard, "Discreet but Deadly," Globe and Mail, 25 May 1996; Filip Reyntjens, "Estimation du nombre de personnes Tuées au Rwanda en 1994," in L'Afrique des Grands Lacs: Annuaire 1996-1997, by Stefaan Marysse and Filip Reyntjens (Paris: L'Harmattan, 1997), 179-86; James K. Gasana, Rwanda: du parti-état à l'état-garnison (Harmattan, 2002), 185; United Nations, "Report of the 
Mapping Exercise Documenting the Most Serious Violations of Human Rights and International Humanitarian Law Committed within the Territory of the Democratic Republic of the Congo between March 1993 and June 2003," August 2010; Alan J. Kuperman, "The Puzzle of Rwanda's Genocide: Why Kill Civilians While Losing to Rebels?" (conference paper, Annual Meeting of the American Political Science Association, Washington, DC, 5 September 2010).

21. See, for example, Mary Anderson, Do No Harm: How Aid Can Support Peace-Or War, (Boulder, CO: Lynne Reinner, 1999); John Prendergast, Frontline Diplomacy: Humanitarian Aid and Conflict in Africa (Boulder, CO: Lynne Reinner, 1996); Alexander de Waal, Famine Crimes; Politics and the Disaster Relief Industry in Africa (Bloomington, IN: Indiana University Press, 1998); Fiona Terry, Condemned to Repeat: The Paradox of Humanitarian Action (Ithaca, NY: Cornell University Press, 2002).

22. Alan J. Kuperman, "The Other Lesson of Rwanda: Mediators Sometimes Do More Damage than Good," SAIS Review 16, no. 1 (1996): 221-40.

23. Alan J. Kuperman, "Ripeness Revisited: The Perils of Muscular Mediation," in Conflict Management and Africa: Negotiation, Mediation, and Politics, ed. Terrence Lyons and Gilbert Khadiagala (Abingdon: Routledge, 2008): 9-21.

24. Alan J. Kuperman, "Mitigating the Moral Hazard of Humanitarian Intervention: Lessons from Economics," Global Governance 14, no. 2 (2008): 219-40. 